\title{
Artan Öğrenci Artan Kamu Harcaması Anlamına Gelir Mi? Türkiye'de Devlet Üniversiteleri Üzerine Bir Analiz
}

\author{
İsmail Sadık Yavuz ${ }^{*}$, Murat Ali Dulupçu² \\ 'Süleyman Demirel Üniversitesi İktisadi ve Idari Bilimler Fakültesi Maliye Bölümü, ismailyavuz@sdu.edu.tr, ORCID-ID: 0000-0002-0070-1363 \\ ²üleyman Demirel Üniversitesi İktisadi ve İdari Bilimler Fakültesi Iktisat Bölümü, muratdulupcu@sdu.edu.tr, ORCID-ID: 0000-0001-9269-5978
}

\begin{abstract}
Özet
İlk insandan günümüze kadar insanoğlu bilinmeyeni öğrenmeye çalıșmıştır. Bilinmeyeni öğrenmek için ise üniversiteler tercih edilen ilk kaynaklardan birisi olmuștur. Zaman içerisinde üniversitelere artan talep, üniversite sayısının artması ve üniversitelerin hacimlerinin büyümesi ile sonuçlanmıștır. Bu durum ise üniversitelere aktarılan finansmanın artması sonucunu doğurmuştur. Gerekli olan finansman kaynaklarının uygulamada tek tiplilik arz etmediği ve çeşitlendiği görülmüstür.

Bu çalışmada Türkiye'de devlet tarafından finanse edilen üniversitelerin harcamaları ile öğrenci sayıları arasındaki bir ilişkinin varlığı tespit edilmeye çalışılmıştır. Bu amaç doğrultusunda 2006 öncesi kurulan 53 devlet üniversitesi incelemeye alınmıștır. Zaman dilimí olarak 2006-2016 yılları arası belirlenmiștir. Yıl bazlı kullanılan ön lisans, lisans, yüksek lisans, doktora öğrenci sayıları ve üniversite harcamaları temel değişkenler olarak tanımlanmıștır. Analiz olarak sabit etkiler modelinden yararlanılarak panel veri analizi kullanılmıștır.

Yapılan analiz sonucunda öğrenci sayıları ile harcamalar arasında pozitif yönlü doğrusal ve güçlü bir ilişki tespit edilmiștir. Öğrenci sayılarının artmasının dolaylı etkileri sonucunda devlet üniversitelerinde yapılan harcamaların arttığı tezi öne sürülmüştür.
\end{abstract}

Anahtar Kelimeler: Yükseköğretim Harcamaları, Yükseköğretim Öğrenci Sayıları, Panel Veri Analizi

\section{Does Increasing Number of Students Mean to Increasing Public Expenditures? An Analysis on State Universities in Turkey}

\begin{abstract}
From the first person to the present, human beings have tried to learn the unknown. In order to learn the unknown, universities have become one of the first preferred sources. The increasing demand for universities over time has resulted in an increase in the number and volume of the universities. This resulted in an increase in the funding that was transferred to universities. It has been observed that the required funding sources do not have uniformity and are diversified in practice.

In this study, the existence of a relationship between spending and student numbers at universities funded by the government in Turkey has tried to be determined. For this purpose, 53 state universities that were established before 2006 were examined. The time frame was set between 2006 and 2016. Associate, bachelor, master, doctoral student numbers and university expenditures are defined as the main variables. Panel data analysis was performed using the fixed effect model as an analysis.

As a result of the analysis made, a positive, linear and strong relation was found between student numbers and expenditures. It has been determined that expenditures made in state universities have increased due to the indirect effects of the increase in student numbers.
\end{abstract}

Key Words: Higher Education Expenditures, Number of Students in Higher Education, Panel Data Analysis

\section{Giriş̧}

Yükseköğretimin kökenlerini Sokrates'in Academia'sına (M.Ö. 400), Aristo'nun Lyceum'una (M.Ö.387) ve hat-

*Yazışma Adresi / Address for Correspondence: İsmail Sadık Yavuz, Email: ismailyavuz@sdu.edu.tr

Geliş Tarihi / Received Date: 15.02.2018

Kabul Tarihi / Accepted Date: 23.07.2018

Doi: $10.26701 /$ uad.395413 ta bir araștırma kurumu niteliğini taşıması nedeniyle, İskenderiye Müzesi'ne (M.O.330-200) kadar götürmek mümkündür (Gürüz, 2003:1). Ancak batılı anlamdaki ilk üniversitesinin 1088 yılında kurulmuş olan Bologna Üniversitesi olduğu genel literatürde kabul edilmektedir ${ }^{1}$ (de

${ }^{1}$ Ancak ilk üniversitelerin kökeni çok karmaşık bir süreçtir. Üniversiteler kendilerini oluşturan çeşitli unsurlardan birine bağlı olarak en eski üniversite olarak adlandırılabilmektedir. Eğer tek bir kurumsal varlığın olması ana kriter olarak belirlenirse, Bologna Üniversitesi en eskidir. Fakat çeşitli disiplinlerden öğretmenlerin ve öğrencilerin birlikteliği 
Ridder-Symoens, 2003:4). Üniversitelerin sunmuș oldukları hizmetlerin maliyetlerinin yüksek olması, gerekli olan finansmanın nasıl temin edileceği konusunu da beraberinde getirmiş ve bu durum geçmişten günümüze kadar tartışılmaya devam etmiştir. Şöyle ki tarihteki ilk açılan üniversiteler olan Bologna, Paris ve Oxford üniversitelerine bakıldığında; Bologna Üniversitesi'nde öğretmenlerin maaşlarını öğrencilerin karşıladığı, Paris Üniversitesi'nde öğretmen maaşlarının kilise tarafından karşılandığı, Oxford Üniversitesi'nde ise öğretmen maaşlarının devlet tarafından karşılandığı görülmektedir (Antalyalı, 2007:27). Türkiye Cumhuriyeti Devleti yükseköğretim tarihi incelendiğinde bir üniversitenin temellerini oluşturabilecek ve ilk laik eğitim kurumu olarak tanımlanabilecek kurum İstanbul'da 1773 yllında kurulan Mühendishane-i Bahri-i Hümayun'undur (Baskan, 2014:24).

Hem Dünya'da hem de Türkiye'de ilk üniversitelerin kurulmasından günümüze kadar üniversiteler hem yapısal hem de finansal hacim açısından hızlı bir şekilde büyümüștür. Bu büyüme beraberinde özellikle kamu yolu ile finanse edilen devlet üniversitelerin harcamalarının neler olduğu sorusunu da beraberinde getirmiștir.

Bu çalışma 2005 ve öncesinde kurulan devlet üniversitelerinin harcamalarının, önemli bir belirleyicisi olduğu düşünülen öğrenci sayıları ile ilişkisini incelemektedir. Bu inceleme için öncelikle devlet üniversitelerinin kanuni finansman araçları ve harcama yapısı mevzuat çerçevesinde irdelenmiş, sonrasında ise üniversitelerin harcamaları ile öğrenci sayıları arasındaki ilişki istatistiki olarak analiz edilmiştir.

\section{TÜRKIYE'DE DEVLET ÜNIVERSITELERININ HARCAMA YAPILARI}

Türkiye'de üniversitelerin eğitim öğretim faaliyetlerinin nasıl yapılacağı ve uyulması gereken yasal mevzuat 2547 sayllı Yükseköğretim Kanunu'nda belirtilmiștir. Kanun'un 3. maddesindeki tanıma göre üniversite: "Bilimsel özerkliğe ve kamu tüzelkişiliğine sahip yüksek düzeyde eğitim - öğretim, bilimsel araştırma, yayın ve danışmanlık yapan; fakülte, enstitü, yüksekokul ve benzeri kuruluş ve birimlerden oluşan bir yükseköğretim kurumudur" şeklinde tanımlanmıştır. Bu tanımdan yola çıkılarak üniversitelerin kazandıkları tüzel kişilikleri ile ekonomik yapıları arasında 5018 sayılı Kamu Mali Yöntemi ve Kontrol Kanunu aracilığıyla yasal ve mali bir ilişki kurulmuştur. 5018 sayılı kanunun ikinci bölümünü olușturan merkezi yönetim bütçe kanunu hakkındaki hükümler gereğince; kendi tüzel kişiliklerine haiz olan devlet üniversitelerinin harcama yapabilmeleri için gerekli olan mali fonlar devlet tarafından sağlanmaktadır. Kanunda üniversite bütçeleri için temel iki harcama türü öngörülmüștür. Bunlar cari harcamalar ve yatırım harcamalarıdır. Kamu üniversitelerin yıl içerisinde harcama yapabilmesi için her yıl cari ana kriter olarak belirlenirse en eski üniversite 1208'de kurulan Paris Üniversitesi olacaktır (de Ridder-Symoens, 2003:6). ve yatırım harcama teklifleri öncelikle kamu bürokrasisindeki teknik; Türkiye Büyük Millet Meclisi'ndeki yasama görüşmelerinin ardından bütçe kanunu olarak yasalaşması gerekmektedir (Kamu Mali Yönetimi ve Kontrol Kanunu). Kamu üniversite bütçelerinin yasalaşmasının ardından, harcamaların nasıl yapılacağına ve üniversitelerin merkezi hükümet gelirlerinden aktarılandan ayrı olarak elde ettiği diğer gelirlerinin neler olduğun ve nasıl harcanacağına ilişkin diğer hükümler, detaylı bir şekilde 5018 sayılı kanunda ve ikincil diğer mevzuatlarda yer almaktadır ${ }^{2}$.

\section{LITERATÜR}

Üniversitelerin harcamalarına ilişkin literatür incelendiğinde çalışmaların çok geniş bir alana yayıldığı görülmüştür. Üniversitelerin mali olarak inceleyen bu çalışmada, literatürde çok sık rastlanan harcamalar ile eğitim kalitesi/verimliliğini inceleyen çalışmalara değinilmemiştir. Eğitim bilimleri ile ilgili alanlar dışlandığında literatürde iki temel yaklaşımın benimsendiği görülmektedir. Bunlar üniversitelerin hem kendi tüzel kişiliklerini hem de bünyesinde bulunan çalışan ve öğrencileri aracilığıyla bulunduğu bölge/şehir/ülkeye olan katkılarını inceleyen çalışmalar ve devletin mali perspektifini temel alan çalışmalardir.

Ekinci (2009) Türkiye'de yükseköğretimde öğrenci harcamaları ve maliyetleri arasındaki ilişkiyi; öğrenci harcamaları/maliyetleri ve kamusal harcama/maliyeti arasındaki etkileşimleri baz alarak incelemiş ve araştırmadan iki temel sonuç çıkarmıştır. Bunların ilki araştırma kapsamındaki öğrencilerin tamamına yakınının üniversiteye hazırlık harcaması yapması ve öğrencilerin ailelerinin hane halkı gelirleri ile yaptıkları harcamalar arasında olumlu bir ilişki gözlenmesidir. İkincisi ise sağlık bilimleri alanlarındaki bölümlere yerleşen öğrenciler hariç olmak üzere; diğer öğrencilerin eğitim hizmetlerinden yararlanmak için katlandıkları maliyetlerin (üniversiteye hazırlık ve eğitim sürecindeki diğer cari giderler), eğitim hizmetlerinin üretilmesi için devletin katlandığı maliyeti aşmasıdır.

Oruç vd. (2011) 2006 yılı öncesinde kurulmuş olan 53 devlet üniversitesinin, 2007-2009 yılları arasındaki bütçeleri için Yükseköğretim Kurulu tarafından tespit edilen öğrenci başına cari hizmet maliyetleri ile Bakanlar Kurulu tarafından yayınlanan öğrenci başına cari hizmet maliyetlerinin, bütçe kanunuyla tahsis edilen bütçelere

\footnotetext{
2 Bu kanunlar kısaca

06/11/1981 Tarih 2547 Sayılı Yükseköğretim Kanunu

14/7/1965 Tarih 657 Sayılı Devlet Memurları Kanunu

22/01/2002 Tarih 4734 Sayılı Kamu Ihale Kanunu

22/01/2002 Tarih 4735 Sayılı Kamu ihale Sözleşmeleri Kanunu

10/2/1954 Tarih 6245 Sayılı Harcırah Kanunu

TÜBITAK Kaynaklarından Genel Bütçe Kapsamındaki Kamu Idareleri Ille

Özel Bütçeli Idarelere Proje Karşılığı Aktarılacak Tutarların Harcanması

Ve TÜBITAK Tarafından Yürütülen Dış Destekli Projelerin Harcama-

larının Gerçekleştirilmesine Iliş̧kin Esas Ve Usul

- 26 Kasım 2016 Tarihli Yükseköğretim Kurumları Bilimsel Araştırma Projeleri Hakkında Yönetmelik

olarak sayılabilmektedir (SDU Strateji Geliștirme Daire Başkanlığı, 02/02/2018).
} 
yansımalarını incelemişlerdir. Üniversite cari giderlerinin \%60'indan fazlasının personel ile ilgili giderlerden oluștuğu gerçeğinden hareketle üniversiteler arasındaki öğrenci başına düşen cari hizmet harcamaları arasındaki büyük farkların oluşmasındaki ana nedenin öğrenci başına düşen personel sayısı arasındaki fark olduğunu belirtmişlerdir.

Akça (2012) üniversitelerin sunmuş oldukları hizmetler dolayısı ile yaydıkları pozitif dıșsallığı sürdürebilme yolunda karşılaștıkları en önemli sorunun finansman sorunu olduğunu belirtmiștir. Bu sorunu aşmak için bazı ülkelerin yükseköğretimin finansmanında kamu kaynakları kullandığını ancak artan finansman ihtiyacını karşılamak için kamu kaynaklarının yanı sıra alternatif kaynakların da kullanılmaya başlandığını söylemiștir. Bu bağlamda Türkiye'nin nüfus artış hızının yüksek olması ve genç nüfusun fazlalığ sebebi ile yükseköğretime olan talebin artmasının beklendiğini belirtmiştir. Artan talebin ise yeni finansman araçlarını gerektireceği ve kullanılabilecek yöntemlerden birisinin ise gelire bağlı kredi sistemi adı verilen öğrenci borçlanma yöntemi olduğunu savunmuştur.

Selçuk (2012) Ekim 2012'de Atatürk Üniversitesi öğrencilerine yönelik uygulanan anketlerden elde edilen verileri kullanılarak, öğrenci harcamalarını analiz etmiş ve öğrenci harcamalarının il ekonomisine katkısının ne olduğu belirlenmeye çalıșmıștır. Çalışmada üniversite öğrencilerinin bir ayda ortalama 744,66 TL harcama yaptıkları tespit edilmiş ve bu veriden hareketle Atatürk Üniversitesi yerleşkesinde eğitim gören 31.276 öğrencinin, toplamda Erzurum il ekonomisine yaklaşı yılda 186,3 milyon TL katkı sağladıklarını belirlemiştir.

Akçakanat vd. (2014) Süleyman Demirel Üniversitesi öğrencileri ile yaptıkları çalışmada öğrencilerin 2003, 2005, 2007 ve 2009 yıllarında yapmış oldukları harcamaların miktarı, bileșimi ve Isparta ekonomisine katkısını analiz etmişlerdir. Araştırmanın sonucunda 2009 yllı için bir öğrencinin ayda yaklaşık olarak $474 \mathrm{TL}$ harcama yaptığı ve öğrenci harcamalarının Isparta iline yıllık bazda yaklaşı 81.000.000 TL’lik bir katkı sağladığı tespit etmişlerdir. Öğrencilerin toplam harcamalarının yaklaşı \%60'ının ise barınma ve beslenme amaciyla yaptıkları bulgularına ulaşmışlardır.

Çayın \& Özer (2015) Muş Alparslan Üniversitesi öğrencilerine uygulanan anketlerden elde edilen veriler ile üniversitenin gelir, istihdam ve harcama bakımından il ekonomisine yaptığı katkıyı ve öğrencilerin tüketim yapısını belirlemeye çalışmışlardır. Çalışmanın sonucunda Muş Alparslan Üniversitesinin 2010-2011 eğitim-öğretim döneminde Muş iline 417 kişilik dolaysız istihdam ve 477 kişilik dolaylı istihdam olmak üzere toplamda 894 kişilik bir istihdam katkısı oluşturduğu belirtmişlerdir. İlgili dönemde üniversitenin 11.075.394 TL dolaysız gelir katkısı ve 29.587.176 TL dolaylı gelir katkısı olmak üzere toplamda 40.662.570 TL gelir katkısı sağladığını tespit etmişlerdir.

\section{TÜRKIYE'DE DEVLET ÜNIVERSITELERININ HARCAMA ANALIZI}

Çalışmanın bu bölümü iki alt bölüme ayrılmıştır. Öncelikle veriler tanımlanmış, sayısal değerler nicel bir araştırma için grafikler yardımı ile görselleştirilmiş ve istatistiki analiz öncesi genel bir çerçeve çizilmiştir. Daha sonra analizde kullanılan metot olan panel veri analizinin teorik ve metodolojik çerçevesi özet olarak verilmiş ve analizler gerçekleştirilmiştir.

\subsection{Veriler}

Analizlerde 2006 ve öncesinde kurulan devlet üniversitelerine ait kümülatif harcamaları $(\mathrm{H})$, birinci ve ikinci öğretim öğrenci sayıları toplanarak oluşturulmuş ön lisans (OL), lisans (L), yüksek lisans (YL) ve doktora (DR) öğrenci sayıları veri olarak kullanılmıştır. Zaman dilimi olarak yıl bazlı 2006-2016 dönemi belirlenmiştir. Başlangıç yılının 2006 olarak belirlenmesinin sebebi 5018 sayılı Kamu Mali Yönetim ve Kontrol Kanunu'nda II Sayılı Cetvel'de tanımlanan Özel Bütçeli İdareler kapsamında yer alan Yükseköğretim Kurumu ve Üniversite bütçelerinin 2006 yllından itibaren yayımlanmasıdır. 2016 yılının bitiş yılı olarak belirlenmesi ise 2017/2018 eğitim ve öğretim yılına ilişkin öğrenci istatistiklerinin çalışmanın yapıldığı tarihte henüz yayınlanmamış olmasıdır. Kesit olarak 2006 öncesi kurulan devlet üniversitelerinin seçimindeki temel kriter zaman serilerinin uzatılarak istatistiki anlamlllığı yükseltmektir.

Öğrenci istatistikleri Yüksek Öğretim Kurulu (YÖK) İstatistik veri tabanından, harcama verileri ise Muhasebat Genel Müdürlüğünce yayımlanan bütçe kesin hesaplarından alınarak tarafımızca derlenmişsir. Analizlerde yatay kesitte 53 üniversite olmasından ve bu durum şekil ve tablolarda görsel karışıklık yaratmasından dolayı kuruluş yılları baz alınarak üniversiteler nümerik olarak 1'den 53'e kadar s1ralanmış ve isimlendirilmiştir. Tablo 1'de üniversitelerin kuruluş yılları baz alınarak hazırlanmış üniversite kodları yer almaktadır.

Çalışmada ilk olarak verilerin tanımlayıcı istatistikleri özetlenmiştir. Tanımlayıcı istatistiklerin anlaşılabilirliklerinin artırılması için grafikler aracılı̆̆ılyla görsellerden yararlanılmıştır. Tanımlayıcı istatistikler yalnızca verilerin yapısını tanımlamak için değil aynı zamanda analize temel oluşturması açısından dikkate alınmasından dolayı, üniversiteler bazında öğrenci başına harcama yapısı da incelenmiştir.

Şekil 1'de ylllar itibari ile üniversitelerin kümülatif harcamalarının ortalamaları görülmektedir. Kümülatif verilerin kullanılmasından ve üniversitelerin harcamaları arasındaki yüksek farklılıklardan dolayı $+/-1$ standart sapma eğrilerine de şekilde yer verilmiştir. Şekil 1 incelendiğinde yıllar itibari ile üniversitelerin cari fiyatlar ile harcamalarının 2011 yllı hariç olmak üzere yükseldiği görülmektedir. 2006 yılında ortalama olarak 100 milyon TL olan üniversite bazındaki harcamalar 2016 yllına gelindiğinde 300 milyon TL sınırına ulaşmıştır. 
Tablo 1. Kuruluş Yılı Bazında Devlet Üniversiteleri

\begin{tabular}{|c|c|c|c|c|c|}
\hline No & Üniversite Adı & $\begin{array}{c}\text { Kuruluş } \\
\text { Yılı }\end{array}$ & No & Üniversite Adı & $\begin{array}{c}\text { Kuruluş } \\
\text { Yılı }\end{array}$ \\
\hline 1 & İstanbul Üniversitesi & 1924 & 28 & Gaziantep Üniversitesi & 1987 \\
\hline 2 & İstanbul Teknik Üniversitesi & 1944 & 29 & Abant İzzet Baysal Üniversitesi & 1992 \\
\hline 3 & Ankara Üniversitesi & 1946 & 30 & Adnan Menderes Üniversitesi & 1992 \\
\hline 4 & Ege Üniversitesi & 1955 & 31 & Afyon Kocatepe Üniversitesi & 1992 \\
\hline 5 & Karadeniz Teknik Üniversitesi & 1955 & 32 & Balıkesir Üniversitesi & 1992 \\
\hline 6 & Atatürk Üniversitesi & 1957 & 33 & Bülent Ecevit Üniversitesi & 1992 \\
\hline 7 & Orta Doğu Teknik Üniversitesi & 1959 & 34 & Celal Bayar Üniversitesi & 1992 \\
\hline 8 & Hacettepe Üniversitesi & 1967 & 35 & Çanakkale Onsekiz Mart Üniversitesi & 1992 \\
\hline 9 & Boğaziçi Üniversitesi & 1971 & 36 & Dumlupınar Üniversitesi & 1992 \\
\hline 10 & Anadolu Üniversitesi & 1973 & 37 & Gaziosmanpaşa Üniversitesi & 1992 \\
\hline 11 & Çukurova Üniversitesi & 1973 & 38 & Gebze Teknik Üniversitesi & 1992 \\
\hline 12 & Dicle Üniversitesi & 1973 & 39 & Harran Üniversitesi & 1992 \\
\hline 13 & Cumhuriyet Üniversitesi & 1974 & 40 & İzmir Yüksek Teknoloji Enstitüsü & 1992 \\
\hline 14 & Fırat Üniversitesi & 1975 & 41 & Kafkas Üniversitesi & 1992 \\
\hline 15 & İnönü Üniversitesi & 1975 & 42 & Kahramanmaraş Sütçü İmam Üniversitesi & 1992 \\
\hline 16 & Ondokuz Mayıs Üniversitesi & 1975 & 43 & Kırıkkale Üniversitesi & 1992 \\
\hline 17 & Selçuk Üniversitesi & 1975 & 44 & Kocaeli Üniversitesi & 1992 \\
\hline 18 & Uludağ Üniversitesi & 1975 & 45 & Mersin Üniversitesi & 1992 \\
\hline 19 & Erciyes Üniversitesi & 1978 & 46 & Muğla Sıtkı Koçman Üniversitesi & 1992 \\
\hline 20 & Akdeniz Üniversitesi & 1982 & 47 & Mustafa Kemal Üniversitesi & 1992 \\
\hline 21 & Dokuz Eylül Üniversitesi & 1982 & 48 & Niğde Üniversitesi & 1992 \\
\hline 22 & Gazi Üniversitesi & 1982 & 49 & Pamukkale Üniversitesi & 1992 \\
\hline 23 & Marmara Üniversitesi & 1982 & 50 & Sakarya Üniversitesi & 1992 \\
\hline 24 & Mimar Sinan Güzel Sanatlar Üniversitesi & 1982 & 51 & Süleyman Demirel Üniversitesi & 1992 \\
\hline 25 & Trakya Üniversitesi & 1982 & 52 & Eskişehir Osmangazi Üniversitesi & 1993 \\
\hline 26 & Yıldız Teknik Üniversitesi & 1982 & 53 & Galatasaray Üniversitesi & 1994 \\
\hline 27 & Yüzüncü Yıl Üniversitesi & 1982 & & & \\
\hline
\end{tabular}

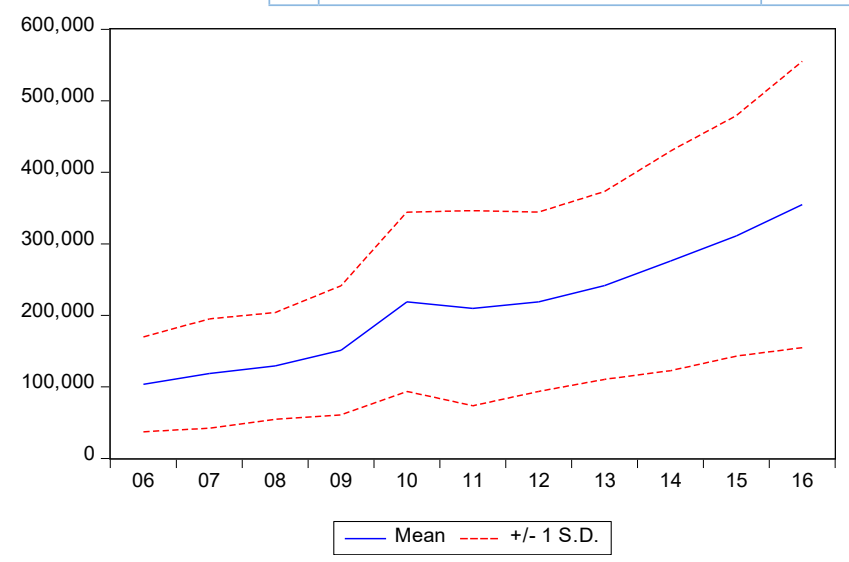

Şekil 1. Kümülatif Üniversite Harcamaları (Cari Fiyatlarla/Bin TL)

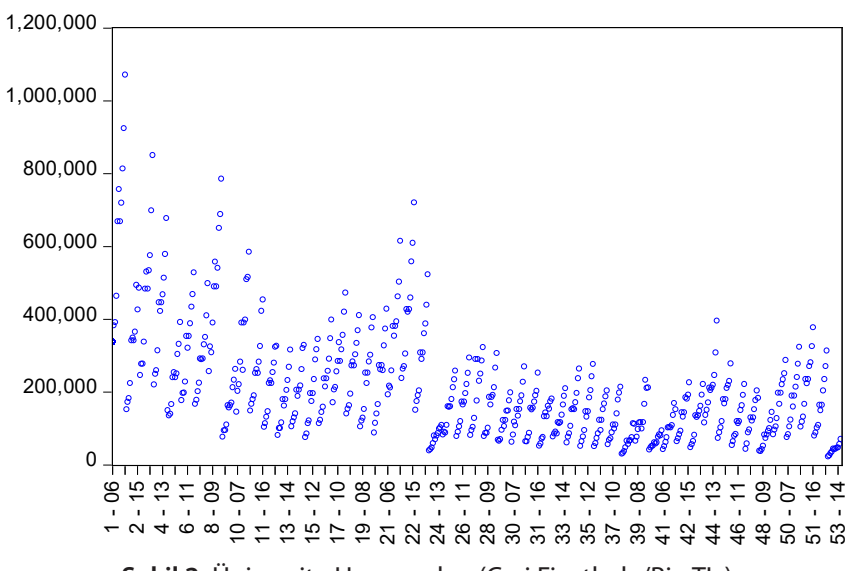

Şekil 2. Üniversite Harcamaları (Cari Fiyatlarla/Bin TL)

Şekil 2'de her bir üniversitenin yıllar itibari ile harcamalarındaki değişimler görülmektedir. Genel olarak üniver- sitelerin yaşının artmasının harcamalarında artması ile sonuçlandığı görülmektedir. 2016 yılı verileri incelendiğinde en yüksek harcamayı 1 milyar TL'den daha yüksek bir harcama yapan İstanbul Üniversitesi'nin, en düşük harcamayı ise yaklaşı 93 milyon TL ile İzmir Yüksek Teknoloji Enstitüsü’nün gerçekleştirdiği görülmektedir. $\mathrm{Bu}$ yüksekliğin sebebini açılayan etkenler öğrenci say1larının fazlalığından kaynaklı cari bütçesinin büyüklüğü olabileceği gibi toplam bütçesinin büyüklüğü de olabilmektedir. Bu farkın açıklanabilmesi ve kısmi bir karşılaştırma yapılabilmesi için Şekil-3'te öğrenci başına düşen harcamalar incelenmiştir.

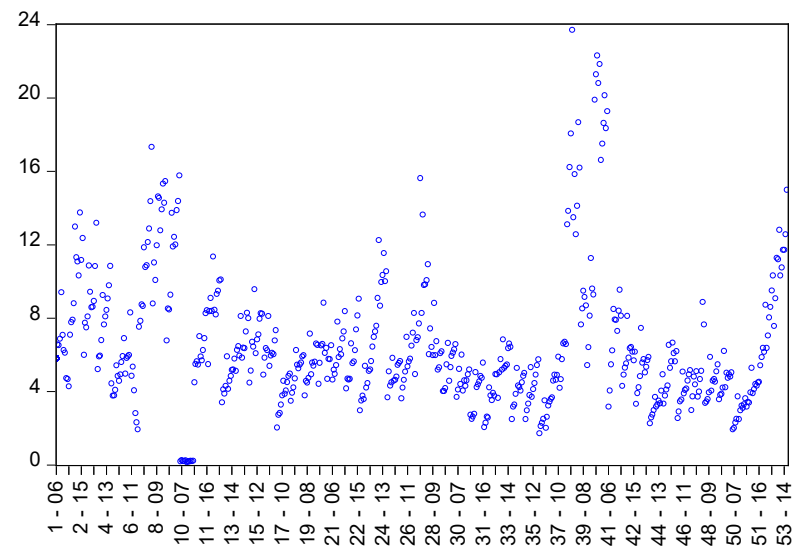

Şekil 3. Öğrenci Başına Üniversite Harcamaları (Cari Fiyatlarla/Bin TL)

Şekil 3’teki grafikte yıllar ilerledikçe cari fiyatlar ile öğrenci başına yapılan harcamaların tıpkı kümülatif harcamalarda olduğu gibi arttığı görülmektedir. Ancak öğrenci 
başına harcamalar incelendiğinde üniversiteler arasında çok büyük farklar gözlemlenmiştir. Şöyle ki 2016 yılı için öğrenci başına en düşük harcama Anadolu Üniversitesi’nde yalnızca 193 TL ile gerçekleşmiştir. En yüksek harcama ise 19245 TL ile İzmir Yüksek Teknoloji Enstitüsünde tespit edilmiştir. Öğrenci başına harcamalar dikkate alındığında 100 kata varan bu farkın temel nedeninin üniversiteler bünyesindeki toplam öğrenci değil, öğrencilerin profili olduğu anlaşılmaktadır. Üniversitelerde yer alan açık öğretim programları ve ön lisans programlarındaki öğrenci sayıları arttıkça öğrenci başına harcama düşmekte fakat toplam harcama miktarı yükselmektedir.

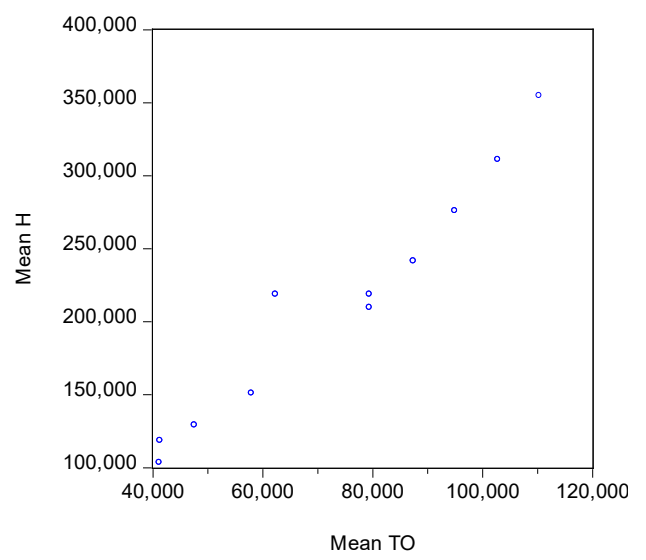

Şekil 4. Toplam Öğrenci Üniversite Harcamaları Arasındaki Illişki-1 (Cari Fiyatlarla/Bin TL )
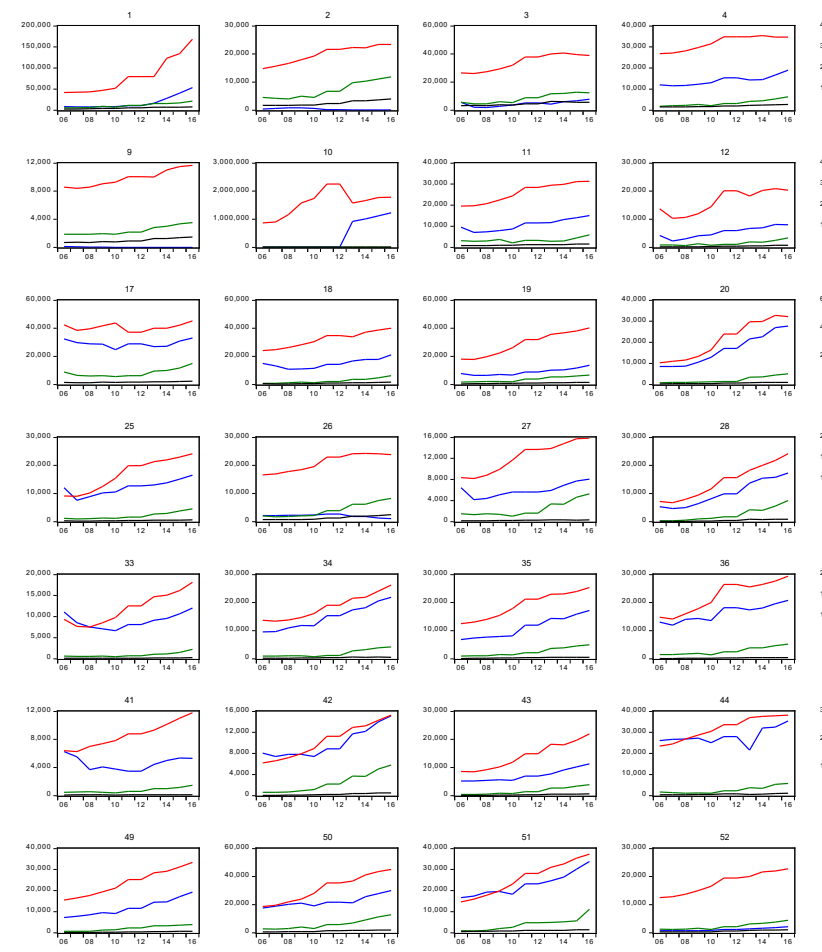

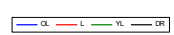

Şekil 6. Eğitim Kademesine Göre Üniversite Bazında Öğrenci Sayıları
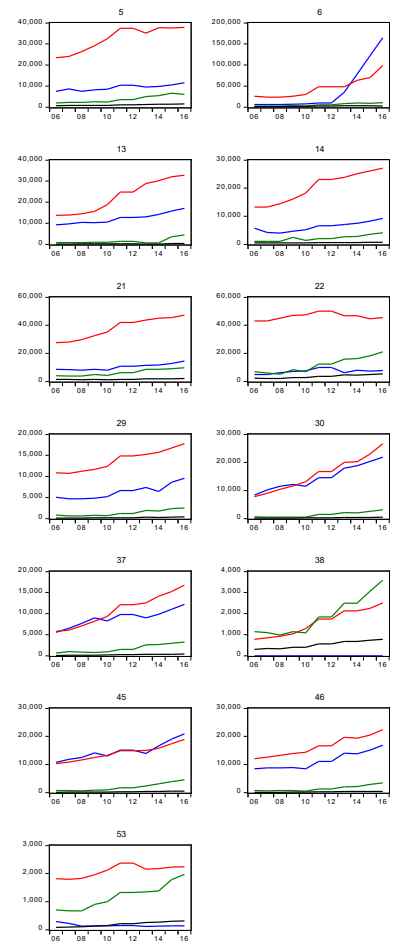

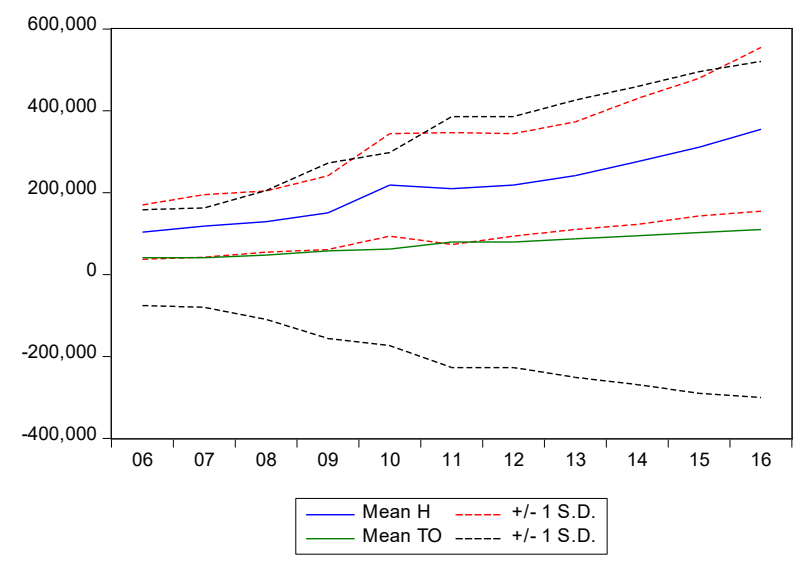

Şekil 5. Toplam Öğrenci Üniversite Harcamaları Arasındaki İlişki-2 (Cari Fiyatlarla/Bin TL )

Şekil 5'te yıllar itibari ile toplam öğrenci sayıları (TO) ve üniversitelerin toplam harcamalarının $(\mathrm{H})$ ortalamaları görülmektedir. Şekil 2, 3 ve 4’ü destekler nitelikteki grafiğe göre öğrenci sayıları ile harcamalar arasındaki pozitif yönlü ilişki bu grafikte de görülmektedir.

Şekil 6 her bir üniversite bazında öğrenci sayılarını göstermektedir. Kırmızı çizgi ile belirtilen lisans öğrenci sayısının çoğu üniversitede toplam öğrenci sayıları içerisindeki sıralamada ilk sırayı aldığı görülmektedir. Ancak bu duruma ilişkin birkaç istisna bulunmaktadır. Atatürk Üniversitesi'nde (6 numaralı üniversite) açı öğretim
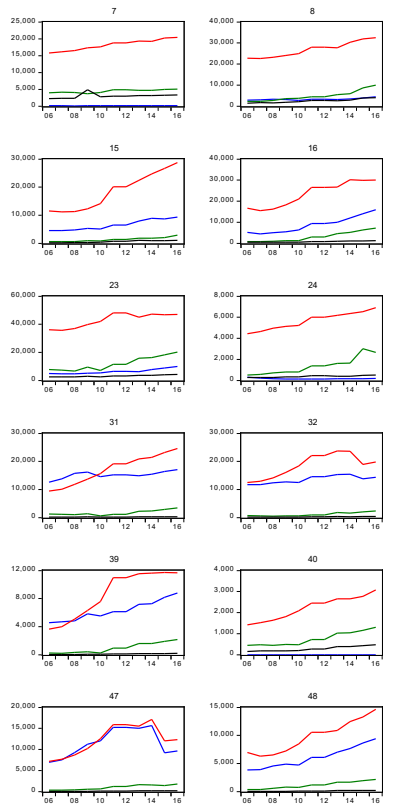

Şekil 4'te ekseninde yer alan toplam harcama $(\mathrm{H})$ ortalaması ile ekseninde yer alan toplam öğrenci sayılarının (TO) ortalamalarını içeren box-plot grafiği ile Şekil 2'yi destekler bulgular elde edilmiș ve toplam harcamalar ile öğrenci sayıları arasında pozitif yönlü bir ilişki görsel olarak ortaya çıkmıştır. programından dolayı ön lisans öğrenci sayısının yüksek olduğu, Balıkesir Üniversitesi'nde (31 numaralı üniversite) 2010 yllından itibaren lisans öğrenci sayısının ön lisansı geçtiği, Gebze Teknik Üniversitesi'nde (38 numaralı üniversite) yüksek lisans öğrenci sayısının nominal olarak ve doktora öğrencisinin ise oransal olarak en yüksek üni- 
versite olduğu, İzmir Yüksek Teknoloji Enstitüsü'nde ise yüksek lisans ve doktora öğrencileri toplamının lisans düzeyine ortalamasının yaklaşık \%50 olduğu görülmektedir. Şekil 6'da incelenen eğitim kademesine göre öğrencilerin dağılımı ile Şekil 3'te incelenen öğrenci başına yapılan harcamalar arasında pozitif yönlü bir ilişki olduğu görülmektedir. Bu ilişki için verilen eğitim seviyesi arttıkça, öğrenci başına harcamalar yükselmektedir önermesinin geçerli olacağı düşünülmektedir.

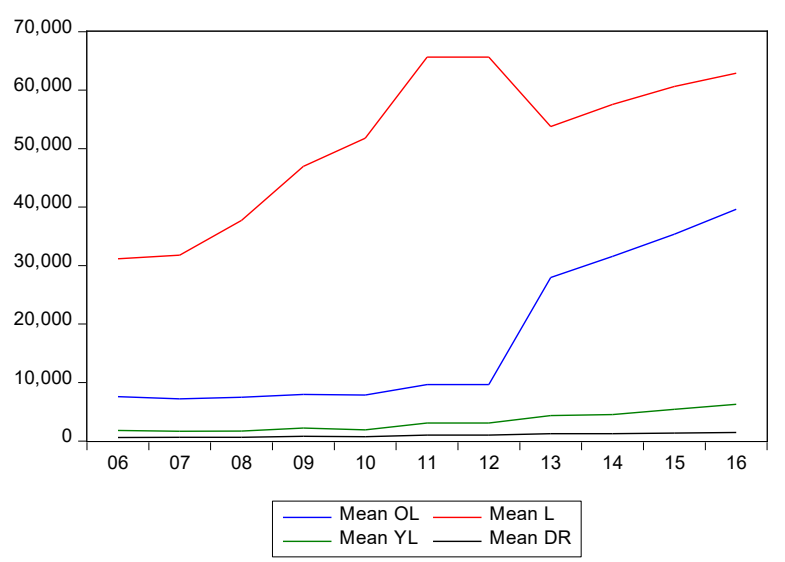

Şekil 7. Eğitim Kademesine Göre Ortalama Öğrenci Sayıları

Şekil 7'de inceleme altına alınan üniversiteler için eğitim kademesine göre ortalama öğrenci sayıları gösterilmiştir. Şekilde "OL" ön lisans programlarına yerleșen öğrenci sayısını, " $L$ " lisans programlarına yerleșen öğrenci sayısını, " $Y L$ " yüksek lisans programlarına yerleșen öğrenci sayısını, " $D R$ " ise doktora programlarına yerleşen öğrenci sayısını ifade etmektedir. 53 üniversite için bakıldığında 2012/2013 eğitim ve öğretim yılı lisans yerleştirmeleri ${ }^{3}$ hariç olmak üzere öğrenci sayılarının sürekli arttığı görülmektedir.

\subsection{Panel Veri Analizi}

Bu bölümde ilk adımda panel veri analizini teorik ve metodolojik çerçevesi çizilmiş, ikinci adımda ise analize ve bulgulara yer verilmiştir.

\subsubsection{Teorik ve Metodolojik Çerçeve}

Zaman ve kesit bileşenlerinin aynı anda bulunduğu veri setlerinin çözümlemesi panel veri analizleri aracilığıyla gerçekleștirilmektedir. Panel veri analizlerinin ekonomi ve siyaset bilimlerinde kullanılabildiği (Bell \& Jones, 2015:132)solvable with Mundlak's (1978a gibi eğitim bilimlerinde (O'Connell \& McCoach, 2008), tıp bilimlerinde (Duncan vd., 1998) ve coğrafya bilimi (Jones, 1991) gibi çeşitli bilim dallarında da sıkıkla kullanıldığı görülmektedir.

Panel veri modellerini temelde iki gruba ayırmak mümkündür. Bunlar sabit etkiler ve tesadüfi etkiler modelleridir (Schurer \& Yong, 2012:1). Sabit etkiler modellemesi, iktisat ve siyaset biliminde daha sık kullanılmakla beraber; hiyerarşik doğrusal modeller veya karma modeller

${ }^{3}$ Illgili düşüşün sebebi olarak lisans yerleştirme puanların hesaplanırken katsayıların 0,15'ten 0,12'ye düşürülmesi nedeniyle öğrencilerin yeşertime barajı alıında kalması düşünülmektedir. olarak da adlandırılan tesadüfi etkiler modelinin de giderek önemi artmıştır (Beck \& Katz, 2007:182-183).

Çeşitli bilim dallarında kullanılan panel veri modellerinde, $N$ tane birim ve her birime karşı gelen $T$ adet gözlem bulunmaktadır. İki boyutun bir arada kullanılması sonucunda oluşturulan matrislerde serbestlik derecesinde artış sağlamakta ve gözlem sayısındaki artış, ölçülen ilişkiye daha fazla değişkenlik katarak, çoklu doğrusal bağıntı problemini ortadan kaldırmaktadır (Arı \& Zeren, 2014:41) Zaman serilerinde olduğu gibi panel veri setlerinde de tahmincilerin tutarlı ve istatistiki olarak geçerli olabilmesi için serilerin durağan olması gerekmektedir. Çünkü durağan olmayan serilerin kullanılması durumunda regresyon tahminci katsayılarının verimsiz olması, regresyon sonuçlarının doğruyu yansıtmaması sorunları ile karşılaşılabilmektedir (Granger \& Newbold, 1974:111112). Bu sorunlardan kaçınmak için serilere birim kök testlerinin uygulanması gerekmektedir.

Hem nitel hem de nicel faktörlerin değerlendirildiği bir panel veri modelinin standart gösterimi aşağıdaki gibidir:

$$
\begin{aligned}
Y_{i t}= & \beta_{1}+\sum_{j}^{k} \beta_{j} X_{j i t}+\sum_{p}^{s} \gamma_{p} Z_{p i}+\theta t+\varepsilon_{i t} \\
& i=1, \ldots, N \quad t=1, \ldots, T
\end{aligned}
$$

Standart modelle ilgili yapılan varsayımlara bağlı olarak beş farklı model tahmin etmek mümkündür. Bu modellerde:

- Hem sabit hem de eğim katsayıları hem birimlere hem de zamana göre değişmez ve hata terimi zaman ve birimlere göre oluşan farklıllkları temsil edebilir.

- Eğim katsayıları sabitken, sabit terim birimlere göre değişir, ancak zamana göre sabit kalabilir.

- Eğim katsayıları sabitken, sabit terim birimlere ve zamana göre değișebilir.

- Hem sabit hem de eğim katsayıları birimlere göre değişebilir.

- Tüm katsayılar hem zamana hem de birimlere göre değişebilir (Özer \& Biçerli, 2004:71).

Yukarıda açıklamalar ışığında en genel tanım ile sabit etkiler modeli; yatay kesit birimlerini oluşturan örneklem, herhangi bir tesadüfi örneklem seçimi süreci ile oluşturulmadığında kullanılabilir. OECD ülkeleri veya Avrupa Birliği ülkelerinde olduğu gibi belirli bir coğrafi alan içindeki birlik veya ülkeler grubunda sabit etkiler modeli kullanilabilmektedir (Panel Data: A Selective Survey, 1997:11) Ancak eğer bireysel etkiler ile tanımlayıcı değişkenler arasında güçlü bir korelasyon yoksa ya da birim ana kütlesinden birimsel sabit terim kesit değişkenlerde tesadüfi olarak dağılmıșsa yani bağımlı değişkeni etkileyen çok sayıdaki bağımsız değişkenin açık bir şekilde modele dahil edilememesi durumunda tesadüfi etkiden söz edilebilmektedir (Greene, 2003:293); (Yavuz, 2011). 


\subsubsection{Analiz ve Bulgular}

Değişkenlerde birim kök testi olarak birinci nesil panel birim kök testlerinden birisi olan Levin, Lin\&Chu testi kullanılmıştır4 . Testler sırasında gecikme uzunluğu için Schwarz bilgi kriterinden yararlanılmıştır. Test denklemine hem sabit ham de trend değişkenleri dahil edilerek analiz gerçekleştirilmiştir. Her bir değişken için birim kök testi Tablo 2'de özetlenmiştir.

Tablo 2. Birim Kök Testleri (Seviye)

\begin{tabular}{|c|c|c|c|c|c|}
\hline Değişken & Metot & İstatistik & P Değeri & $\begin{array}{c}\text { Yatay } \\
\text { Kesit }\end{array}$ & $\begin{array}{c}\text { Gözlem } \\
\text { Sayısı }\end{array}$ \\
\hline $\mathrm{H}$ & Levin, Lin \& Chu & -11.6039 & 0.0000 & 53 & 510 \\
\hline $\mathrm{OL}$ & Levin, Lin \& Chu & -1217.91 & 0.0000 & 51 & 491 \\
\hline $\mathrm{L}$ & Levin, Lin \& Chu & -5.78647 & 0.0000 & 53 & 521 \\
\hline $\mathrm{YL}$ & Levin, Lin \& Chu & -3.84771 & 0.0000 & 53 & 496 \\
\hline $\mathrm{DR}$ & Levin, Lin \& Chu & -13.4238 & 0.0000 & 53 & 517 \\
\hline \multicolumn{5}{|c|}{$H_{0}: \rho_{1}=\rho_{2}=\cdots=\rho_{n}=\rho=0$} \\
$H_{1}: \rho_{1}=\rho_{2}=\cdots=\rho_{n}=\rho=0$ & & \\
\hline
\end{tabular}

Tablo 2'de yer toplam harcama miktarı $(\mathrm{H})$, ön lisans programlarına kayıtlı öğrenci sayısı (OL), lisans programlarına kayıtlı öğrenci sayısı (L), yüksek lisans programlarına kayıtlı öğrenci sayısı (YL) ve doktora programlarına kayıtlı öğrenci sayısı (DR) serileri için test sonuçları incelendiğinde 5 seri içinde $H_{0}$ hipotezinin reddedildiği ve serilerin \%99 güven seviyesinde durağan olduğu sonucuna ulaşılmıştır.

Serilerin durağan olduğunun anlaşılmasının ardından tesadüfi veya sabit etkiler modelinin seçimi için test denklemi oluşturulup Housman testi uygulanmıştır.

Tablo 3. Housman Test Sonuçları

\begin{tabular}{|c|c|c|c|c|}
\hline \multicolumn{2}{|c|}{ Test Sonuçları } & $\begin{array}{c}\text { Ki-Kare } \\
\text { İstatistiği }\end{array}$ & Ki-Kare d.f. & P-değeri \\
\hline \multicolumn{2}{|c|}{ Kesit Tesadüfi Etki } & 28.700669 & 4 & 0.0000 \\
\hline \multicolumn{5}{|c|}{ Kesit Tesadüfi Etki Test Sonuçları Karşılaştırması } \\
\hline Değişken & Sabit & Tesadüfi & $\operatorname{Var}($ Diff) & P-değeri \\
\hline $\mathrm{OL}$ & 0.092185 & 0.099170 & 0.000006 & 0.0042 \\
\hline $\mathrm{L}$ & 0.093380 & 0.084846 & 0.000524 & 0.7094 \\
\hline$Y L$ & 24.447207 & 23.595941 & 0.894088 & 0.3680 \\
\hline DR & 58.888739 & 55.703190 & 29.399985 & 0.5569 \\
\hline \multicolumn{2}{|c|}{ Test Sonuçları } & $\begin{array}{c}\text { Ki-Kare } \\
\text { İstatistiği }\end{array}$ & Ki-Kare d.f. & P-değeri \\
\hline \multicolumn{2}{|c|}{ Period Tesadüfi Etki } & 108.08339 & 4 & 0.0000 \\
\hline \multicolumn{5}{|c|}{ Period Tesadüfi Etki Test Sonuçları Karşılaştırması } \\
\hline Değişken & Sabit & Tesadüfi & $\operatorname{Var}($ Diff) & P-değeri \\
\hline $\mathrm{OL}$ & 0.082499 & 0.106591 & 0.000011 & 0.0000 \\
\hline L & 0.062461 & 0.061407 & 0.000000 & 0.0988 \\
\hline $\mathrm{YL}$ & 0.127935 & 5.297341 & 0.340616 & 0.0000 \\
\hline DR & 91.839893 & 83.105128 & 1.042517 & 0.0000 \\
\hline
\end{tabular}

Tablo 3'te özetlenen Housman test sonuçlarına göre hem kesitteki tesadüfi etkiler hem de periyoddaki tesadüfi etkiler modelinin geçerliliği test edilmiştir. Her iki düzey için $H_{0}$ hipotezi reddedilmiş ve sabit etkiler modelinin kullanılmasına karar verilmiştir.

${ }^{4}$ Birinci nesil birim kök testlerinden birisi olan Levin, Lin \& Chu birim kök testinin kullanılabilmesi için yatay kesit bağımsızlığı önşartının gerçekleşmesi gerekmektedir. Aksi takdirde tahminci istatistikler yanıltıcı olabilmektedir (Barberi, 2005:4).
Tablo 4. Test Sonuçları ${ }^{5}$

\begin{tabular}{|c|c|c|c|c|}
\hline \multicolumn{5}{|c|}{ Bağımlı Değişken: H } \\
\hline Değişken & Katsayı & St. Hata & T. İst. & P Değeri \\
\hline $\mathrm{OL}$ & 0.070969 & 0.018986 & 3.737988 & $0.0002^{* *}$ \\
\hline $\mathrm{L}$ & 0.042293 & 0.022059 & 1.917218 & 0.0558 \\
\hline $\mathrm{YL}$ & 6.341594 & 1.699956 & 3.730447 & $0.0002^{* *}$ \\
\hline DR & 67.52458 & 5.930864 & 11.38529 & $0.0000^{* *}$ \\
\hline $\mathrm{C}$ & 121559.0 & 4138.627 & 29.37182 & $0.0000^{* *}$ \\
\hline \multicolumn{5}{|c|}{ Efekt Spesifikasyonu } \\
\hline \multicolumn{2}{|c|}{ R-Kare } & \multicolumn{3}{|c|}{0.960644} \\
\hline \multicolumn{2}{|c|}{ Ayarlanmış R-Kare } & \multicolumn{3}{|c|}{0.955610} \\
\hline \multicolumn{2}{|c|}{ F-İstatistiği } & \multicolumn{3}{|c|}{190.8351} \\
\hline \multicolumn{2}{|c|}{ P-değeri (F-ìstatistiği) } & \multicolumn{3}{|c|}{0.000000} \\
\hline
\end{tabular}

Tablo 4'te sabit etkiler modeline göre oluşturulan modelin sonuçları yer almaktadır. Kurulan modelin F istatistik değeri 190.8351 ve $\mathrm{F}$ istatistiğine ilişkin $\mathrm{p}$ değeri $0.0000<0,05$ olmasından dolayı kurulan model istatistiki açıdan anlamlıdır. Modelin bağımsız değişkenleri olan ön lisans, , yüksek lisans ve doktora öğrenci sayıları \%99 güven seviyesinde, lisans öğrenci sayısı ise \%90 güven seviyesinde anlamlı olarak bulunmuştur. Modelde bağımlı değişken olarak yer alan üniversite harcamalarının bağımsız değişkenler olan ön lisans, lisans, yüksek lisans ve doktora öğrenci sayıları ile açıklanma oranı beklenildiği üzere çok yüksek çıkmış ve $R^{2}=0.96$ olarak bulunmuştur.

Elde edilen bulgulara göre tüm yükseköğrenim kademelerindeki öğrenci sayıları ile üniversitelerin harcamaları arasında pozitif yönlü bir ilişki mevcuttur. Bu ilişkiye ilişkin denklem aşağıda verilmiştir.

$$
\begin{aligned}
H & =121559.0+0.070969 O L+0.042293 L \\
& +6.341594 Y L+67.52458 D R
\end{aligned}
$$

Denklem 2'de yer alan bulgulara göre eğitim kademelerindeki basamaklarda ilerleme kaydedildikçe, öğrenci sayılarının harcamalar üzerindeki etkisinin arttığı gözlemlenmektedir.

\section{5- SONUÇ VE TARTIŞMA}

Üniversitelerden karşılaması beklenen ana görevler nitelikli ve uzmanlaşmış eğitim ve öğretim hizmetleri sunması, araştırmalar yaparak bilime ve insanlığa katkı sağlaması ve uzmanlık alanlarına göre sağlık hizmetleri gibi diğer hizmetleri sunmalarıdır. Üniversitelerin mali kaynakları ölçüsünde sundukları bu hizmetler toplum üzerinde pozitif bir dışsallık oluşturacaktır. Bu sebeple yarı kamusal mal ve hizmet olarak değerlendirilen eğitim hizmetlerinin bir kısmı devlet tarafindan desteklenmekte veya direk karşılanmaktadır. Bu çalışmada finansmanı mükelleflerin vergileri ile karşılanan kamu üniversiteleri için harcanan bütçe ile üniversitelerin eğitim ve öğretim

\footnotetext{
$5 \quad$ Tablo 5. Hata Terimlerine Illiskin Kontrol Testleri

\begin{tabular}{|c|c|c|c|}
\hline Test & İstatistik & d.f. & P-değeri \\
\hline Pasaran CD & 1.084471 & - & 0.2782 \\
\hline
\end{tabular}

Tahmin edilen modelde tahmincilerin anlamlı olabilmesi için hata terimleri arasında yatay kesit bağımlılığının olmaması gerekmektedir. Kurulan modelde hipotezi kabul edilmiş $(P>0,05)$ ve hata terimleri arasında yatay kesit bağımlılığın olmadığı görülmüştür.
} 
hizmetlerinden yararlanan öğrenci sayıları arasındaki ilişki test edilmiştir.

Çalışmada elde edilen temel bulgu öğrenci sayıları ile yapılan harcamalar arasında pozitif yönlü paralel bir ilişki olduğu yönündedir. Modele alınan öğrenci sayılarının artması takdirinde üniversitelerin harcama miktarlarının da arttığı tespit edilmiştir. Bu durumun temel nedeni olarak inceleme altına alınan üniversitelerin toplam harcamalarının \%60-80'ini personel harcamalarına ayırması düşünülmektedir. Öğrenci sayısı arttıkça ihtiyaç duyulan personel sayısı artacak, istihdam edilen personel sayısı artıkça ise toplam harcamalar artacak ve bu durum sarmal şeklinde devam edecektir. Artan öğrenci ve personel sayısı ise daha çok yatırım harcamasının yapılmasını gerekli kılarak toplam harcama düzeyini artırmaya devam edecektir.

Analizin yapıldığı yıllarda genel olarak toplam öğrenci sayılarında yüksek artışlar görülmüştür. Ancak yapılan bu çalışmanın güvenilirliği diğer etkilerin sabit olduğu varsayımına dayanmaktadır. $\mathrm{Bu}$ sebeple çalışmanın en zayıf yönü kümülatif harcama ve öğrenci sayıları verilerinin kullanılmasıdır. Yapılan analizin daha sağlıklı sonuçlar verebilmesi için harcamaların eğitim düzeyleri arasında ayrıştırılması, her bir eğitim düzeyi için direkt harcanan cari giderlerin tespit edilmesi ve genel üniversite bütçesinde yer alan genel yatırım harcamaları gibi alanların detaylandırılması yerinde bir temel oluşturacaktır. Özellikle artan öğrenci sayıları ile birlikte artan yatırım harcamaları ve yapılmış olan bina vb. üstyapı elemanlarının olası bir gelecekte öğrenci sayılarının azalması ile birlikte atıl durumda kalıp kalmayacağının projeksiyonlarının yapılması yararlı olacaktır. Öğrenci sayılarının azaldığının varsayıldığı bir simülasyon aracılığı ile öncelikle yükseköğrenime olan talebin reel olup olmadığı ve mevcut beşeri ve fiziki altyapının nasıl kullanılması gerektiğinin tartışılmasının önemli olduğu düşünülmektedir.

\section{KAYNAKÇA}

Akça, H. (2012). Yükseköğretimin finansmanı ve Türkiye için yükseköğretim finansman modeli önerisi. Yönetim ve Ekonomi: Celal Bayar Üniversitesi Iktisadi ve Idari Bilimler Fakültesi Dergisi, 19(1), 91-104.

Akçakanat, T., Çarıkçı, İ., \& Dulupçu, M. A. (2014). Üniversite öğrencilerinin bulundukları il merkezine ekonomik katkıları ve harcama eğilimleri: Isparta 2003-2009 yılları örneği. Süleyman Demirel Üniversitesi Fen-Edebiyat Fakültesi Sosyal Bilimler Dergisi, 2010(22), 165-178. http://dergipark.gov.tr/sufesosbil/issue/11415/136345

Antalyalı, Ö. L. (2007). Tarihsel süreç içerisinde üniversite misyonlarının oluşumu. Süleyman Demirel Üniversitesi Sosyal Bilimler Enstitüsü Dergisi, (6), 25-40. http://dergipark.gov. tr/sbe/issue/23199/247811

Arı, A., \& Zeren, F. (2014). CO2 emisyonu ve ekonomik büyüme: panel veri analizi. Yönetim ve Ekonomi: Celal Bayar Üniversitesi Iktisadi ve İdari Bilimler Fakültesi Dergisi, 18(2), 37-47. http://dergipark.gov.tr/yonveek/issue/13695/165744
Barberi, L. (2005). Panel Unit Root Tests: A Review.

Baskan, G. A. (2014). Türkiye de yükseköğretimin gelişimi. Gazi Üniversitesi Gazi Eğitim Fakültesi Dergisi, 21(1). http://www. gefad.gazi.edu.tr/issue/6769/91090

Beck, N., \& Katz, J. N. (2007). Random coefficient models for time-series-cross-section data: Monte Carlo experiments. Political Analysis, 15, 182-195.

Bell, A., \& Jones, K. (2015). Explaining Fixed Effects: Random Effects Modeling of Time-Series Cross-Sectional and Panel Data. Political Science Research and Methods, 3(1), 133153. https://doi.org/DOI: 10.1017/psrm.2014.7

Çayın, M., \& Özer, H. (2015). Üniversitelerin il ekonomisine katkısı ve öğrencilerin tüketim yapısı: Muş Alparslan Üniversitesi örneği. Dokuz Eylül Üniversitesi Iktisadi ve Idari Bilimler Fakültesi Dergisi, 30(2).

de Ridder-Symoens, H. (2003). A history of the university in Europe: Volume 1, Universities in the Middle Ages (Vol. 1). Cambridge University Press.

Devlet Memurları Kanunu, Kanun No. 657. Türkiye.

Duncan, C., Jones, K., \& Moon, G. (1998). Context, composition and heterogeneity: using multilevel models in health research. Social Science \& Medicine, 46(1), 97-117.

Ekinci, C. E. (2009). Türkiye'de Yükseköğretimde Öğrenci Harcama ve Maliyetleri. Eğitim ve Bilim, 34(154), 119-133. http:// egitimvebilim.ted.org.tr/index.php/EB/article/view/553

Granger, C. W. J., \& Newbold, P. (1974). Spurious regressions in econometrics. Journal of Econometrics, 2(2), 111-120.

Greene, E. H. (2003). Econometric Analysis. New York: Prentice Hall.

Gürüz, K. (2003). Dünyada ve Türkiye'de yükseköğretim: Tarihçe ve bugünkü sevk ve idare sistemleri. TC Yükseköğretim Kurulu.

Harcırah Kanunu, Kanun No. 6245. Türkiye.

Jones, K. (1991). Specifying and estimating multi-level models for geographical research. Transactions of the Institute of British Geographers, 148-159.

Kamu Ihale Kanunu, Kanun No. No. 4734. Türkiye.

Kamu İhale Sözleşmeleri Kanunu, Kanun No. 4735. Türkiye.

Kamu Mali Yönetimi ve Kontrol Kanunu, Kanun No. 5018. Türkiye.

O'Connell, A. A., \& McCoach, D. B. (2008). Multilevel modeling of educational data. Charlotte: Information Age Publishing.

Oruç, K. O., Çekin, E., Tenderis, A. E., \& Özmen, H. I. (2011). Yükseköğretimde kaynak dağılımı üzerine bir değerlendirme Türkiyedeki devlet üniversitelerinin cari hizmet ödenekleri. Süleyman Demirel Üniversitesi Vizyoner Dergisi, 3(4), 19-34. http://dergipark.gov.tr/vizyoner/issue/23017/246131

Özer, M., \& Biçerli, K. (2004). Türkiye'de Kadın İşgücünün Panel Veri Analizi. Anadolu Üniversitesi Sosyal Bilimler Enstitüsü Dergisi, 3(1), 55-85.

Panel Data: A Selective Survey. (1997). (Discussion Paper Series No. 97-4).

Schurer, S., \& Yong, J. (2012). Personality, well-being and the marginal utility of income: What can we learn from random coefficient models? (Health, Economics and Data Group). 
SDU Strateji Geliştirme Daire Başkanlığı. Devlet Üniversitelerinin harcamalarına ilişkin görüşme. Isparta.

Selçuk, G. (2012). Atatürk üniversitesi öğrencilerinin harcamalarının analizi ve Erzurum ekonomisine katkısı. Atatürk Üniversitesi Sosyal Bilimler Enstitüsü Dergisi, 16(3).

TÜBITAK Kaynaklarından Genel Bütçe Kapsamındaki Kamu İdareleri İle Özel Bütçeli İdarelere Proje Karşılığı Aktarılacak Tutarların Harcanması Ve TÜBiTAK Tarafından Yürütülen Dış Destekli Projelerin Harcamalarının Gerçekleştirilmesi- ne İlişkin Esas Ve Usul.

Yavuz, İ. S. (2011). Avrupa Birliği Adaylık Sürecinde Türkiye'de Mali Sürdürülebilirlik Üzerine Sayısal Bir Uygulama. Süleyman Demirel Üniversitesi.

Yükseköğretim Kanunu, Kanun No. 2547. Türkiye.

Yükseköğretim Kurumları Bilimsel Araştırma Projeleri Hakkında Yönetmelik. 